\title{
Mother's Role in Japanese Family That Reflected in Movie and Serial Drama TV Kazoku Game (Family Game)
}

\author{
Noviyani Prih Handayani ${ }^{1}$, Susy Ong ${ }^{2}$ \\ \{ ${ }^{1}$ noviyaniprih03@gmail.com, ${ }^{2}$ susy.ong66@gmail.com\} \\ ${ }^{1,2}$ School of Strategic and Global Studies, Universitas Indonesia, Indonesia
}

\begin{abstract}
The aim of this research is to find out the changing and the differences mother's role by comparing a family story, Kazoku Game (Family Game), as depicted in a movie released in 1983 and in serial drama TV on air in 2013. I try to examine the mother's role by examining the relations between family members, their attitude toward each other (husband-wife and parents-children), the role in the family, their perception toward work and schooling, and their social life. Japanese society has experienced tremendous changes within the abovementioned period, and family system must also have been changed considerably. By comparing how the family and the attitude of each family members toward mother are depicted on the screen, which can be regarded as representative of the mother's role that widely shared by the general audience, I try to discern the concrete changes that happened in the society, and explain those changes in relation with socio-economical changes in Japanese society during the abovementioned period.
\end{abstract}

Keywords: mother's role, Kazoku games, family, social changes

\section{INTRODUCTION}

In 2013, one of Japanese private television statiom featured a television drama series titled Kazoku Game and starred Sakurai Sho, an actor who were members of the ARASHI band. This television drama attracted the attention of Japanese people as a drama that raised stories about modern families in Japan. This can be seen from the average rating, which is $13.0 \%$ in the Kanto area (www.wiki.d-addicts.com/Source Video Reseaech.Ltd). In addition, this television drama also received many awards, such as the best drama, actors and supporting actors in the 77th Television Drama Academy Awards on August 8, 2013 and in the 17th Nikkan Sports Drama Grand Prix for April-June 2013 period for the same category.

The Kazoku Game (2013) television drama tells about the Numata family consisting of father (Numata Kazushige), mother (Numata Kayoko), and two children named Numata Shin'ichi (first child) and Numata Shigeyuki (second child) who live in big house in a residential complex. Numata family is seen as an ideal family by the surrounding. Kazushige is the head of the family who works in a large company and serves as head of human resources (HR). 
According to the views of the surrounding community, Kazushige is a good father and head of family who is responsible for family life. Kayoko is known as a housewife who is responsible for taking care of children and her husband. Their first child, Shin'ichi, is known as a smart child. The problem in this family is only Shigeyuki. Shigeyuki has problems in learning and is often bullied by his friends at school so he refuses to go to school and confines himself in his room (hikikomori). However, this problem is always covered up by the Numata family. Thus, in the view of others, the Numata family is an ideal family.

Although it looks like an ideal family in the eyes of the community, the Numata family actually has many of problems. Beside the problems with his second child who always tries to be covered, Kazushige, who is the head of the family and breadwinner, actually commits adultery with other younger women. In addition, Kazushige was also fired from his job. Kayoko who is a real housewife also feels depressed because she is not cadoesn't get attention from her husband and children, so because of that, Kayoko follows the invitation of her neighbors to play stock trading. Meanwhile, Shin'ichi, who is known as a model and outstanding child, also likes to do shoplifting (manbiki).

The television drama Kazoku Game 2013 is actually lifted from a novel of the same tittle, Kazoku Game written by Honma Yohei and published by Shueisha in 1982. Before being adapted into a drama, this novel was also raised to the big screen in 1983. Kazoku Game movie directed by Morita Yoshimitsu, starring Itami Juzo, Yuki Saori, and Matsuda Yusaku. The film received awards in various categories, such as the best film, best actor, best supporting actor, and best director in the fifth Yokohama Film Festival held in 1984 in Yokohama.

The Kazoku Game (1983) movie tells the story of the Numata family consisting of Numata Koosuke (father), Numata Chikako (mother) and their two children named Numata Shin'ichi (first child) and Numata Shigeyuki (second child). Koosuke is described as the figure of the head of family head who works in a company. Chikako is a housewife who responsibles for the education of the children. This can be seen from the way she arranges Shin'ichi's schedule in each activity, so that Chikako gets a nickname from Shin'ichi as kyouiku mama ( a mother who concerns about her child's education). Shin'ichi is a smart child and always obeying to the words of his father and mother. Shigeyuki is a child who is lazy, doesn't like to study and likes to exercise. The Numata family lives in an apartment that is not too large.

Shigeyuki is a middle school student who will take the high school entrance examination. Unlike his older brother, Shin'ichi, who was always a model student, Shigeyuki always got bad grades and was ranked last in his class. Because of this reason, Kousuke found a private tutor (Yoshimoto) for Shigeyuki. Kousuke asks Yoshimoto to help Shigeyuki in studying. Yoshimoto is a seventh year student from a third grade university. Even though Yoshimoto came from a non-renowned university, he managed to make Shigeyuki's grades rise slowly until Shigeyuki successfully passed the high school entrance examination. In this film is also told about the relationship between husband and wife between Kousuke and Chikako who look cold but still communicate to each other. The relationship between Shinichi and Shigeyuki as siblings also went badly. Yoshimoto as an outsider can also arbitrarily set and hit Shigeyuki.

The story told in the Kazoku Game (1983) movie is not too different from that shown in television dramas (2013). There are only a few differences, such as the work of the father, the role of the mother in the family, the relationship between family members and the way each family member faces their problems. Compared to films, family problems that occur in 
television dramas are more complex and complicated. This is due to differences and changes in the condition of Japanese society when the movie and television drama Kazoku Game aired.

Kazoku Game movie and television drama get many awards and good ratings. This shows that the movie and television drama, both were well received by the public. Thus, the public acknowledged that the contents of the two works depicted the real life of Japanese society at that time (when movie and television drama aired). From the fragments of the Kazoku Game film and television drama above, it can be seen that family portraits that are reflected in them are not real families. In Japanese, 'kazoku' means family and 'game', which comes from English, meaning game. From the definition of the title of the film and television drama, "kazoku game" can be interpreted as a family game. From the meaning of Kazoku Game, it can be said that the family reflected in this film and television drama is just a group of people who play the role of family without showing their own personalities. This is in line with the expectations of the director who wants to describe the condition of Japanese society when the movie and television drama are aired. The director wants to illustrate that Japanese society generally places their role in the top position and does not show their true 'self' in front of others or better known as honne (words that come out of the real heart) and tatemae (the attitude shown in front other people). This aims to maintain the relationship of roles and values contained in families that are part of a community group.

Through the stories and characterizations featured in the Kazoku Game (1983) movie and the television drama Kazoku Game (2013), it can be seen that Japanese families both from roles, especially the role of mothers and relationships between family members, experience changes in accordance with Japanese social and economic conditions during the film and the television drama aired.

After World War II, Japan experienced a downturn. Many Japanese people experience poverty and suffer from the loss of family and property. To restore the condition of the country, Japan not only prioritizes the quality of human resources by improving the quality of education, but also improves the lifestyle of its people. In addition, Japan also made economic improvements, namely by making improvements to industries and companies, increasing the number of industries and companies, and increasing people's income. According to Hakusho (1956) or the White Records Book, in 1955 Japanese reconstruction had succeeded with a level of production indicator that had recovered and reached the highest level ever achieved before the war, which was around 1937. Japan then began a regular salary payment system for company workers. Workers in companies that get regular salary payments are known as salaryman. This shows that along with the condition of the company which is getting better every year, the community's regular income also increases. With the increase in the amount of community income, the number of public consumption also increased. Thus, the country's economic growth is also getting better.

In addition to improving the quality of human resources and improving the economy, Japan also played an active role in the international world, such as hosting the 1964 Olympics International Sports Week in Tokyo and joining the International Monetary Fund (IMF) in 1965. With the Tokyo Olympics, the number foreigners visiting Japan are increasing, so that state revenues also increase. In addition, with Japan joining the IMF, Japan gained international recognition. With this international recognition, Japan can expand its market abroad, so that the amount of Japanese exports increases. Thus, the amount of state revenue also increases. 
An increase in the amount of state revenue shows that Japan's economic growth is getting better. The increase in the amount of this state income occurred in the period 1955 to 1970s. At this time, Japan entered a fairly high economic growth, or known as the high growth economy. Japan's economic growth can be seen in the graph below.

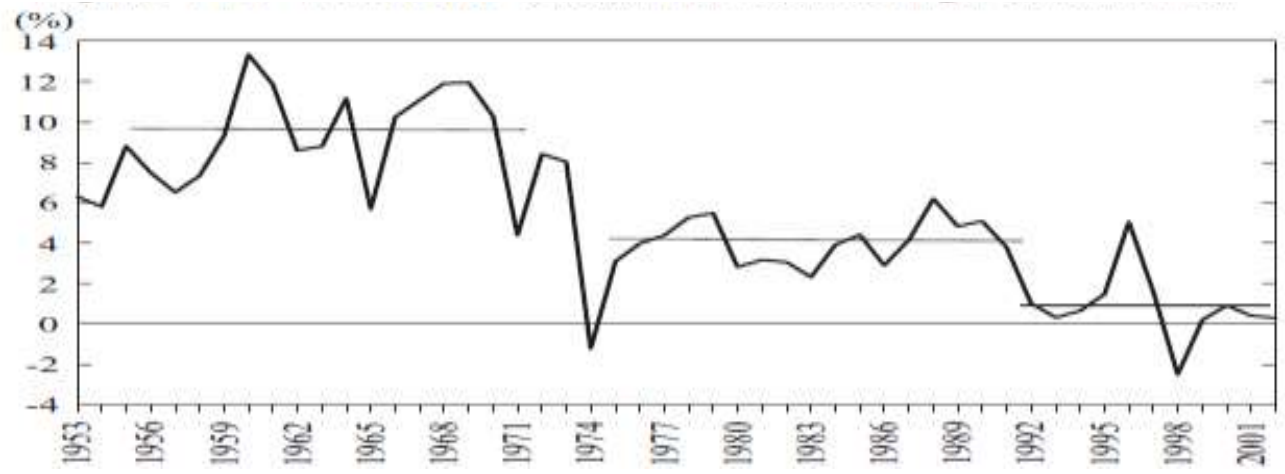

Graph 1. Number of Japanese Revenues Source: (Ohno, 2006: 162)

High economic growth encourages companies to look for qualified workers and open large numbers of jobs to improve company performance. Because of the need for a large number of educated workers, encouraging parents at that time to send their children to the highest levels in the best schools. This is so that their children will be able to work in good companies, get high salaries and live well. If the lives of their children are well established, then the life of parents in their old age is guaranteed. This mindset causes many parents, especially mothers, to regulate all the educational affairs of their children. Mothers who are very concerned and think about the education of their children are also called kyouiku mama.

Entering 1971, the Japanese economy experienced changes due to internal and external influences. In 1971, Japan devalued the yen against the US dollar. US \$ 1 was then pegged to 360 yen and appreciated to 308 yen per dollar. After that the floating value system was imposed which followed the market movement. This is done by the Japanese government with the aim of maintaining the stability of the domestic economy, especially to maintain the stability of exports and imports.

In 1973, the world oil organization (OPEC) raised world oil prices and reduced the oil export quota by $10 \%$ as a result of the war in Middle Eastern countries which became the main source of world crude oil supply. In 1979, Japan also experienced an oil crisis for the second time. This caused Japan's economic conditions to also experience a shock. Many Japanese industries and companies have gone bankrupt, because most of the industries in Japan still use oil as the main fuel. Changes in the structure of oil and energy needs in Japan can be seen in Table 1 below. 
Table 1. Changes of Japan's Energy Needs Structure

\begin{tabular}{|c|c|c|c|c|c|c|c|c|c|c|c|c|c|c|c|c|}
\hline & & & & & & & & & & & & & & \multicolumn{3}{|c|}{ (Satuan : $10^{13} \mathrm{kcal}$ ) } \\
\hline & Tahun & 1965 & 73 & 79 & 86 & 90 & 91 & 92 & 93 & 94 & 95 & 96 & 97 & 98 & 99 & 2000 \\
\hline \multicolumn{2}{|r|}{$\begin{array}{l}\text { Total Pasokan } \\
\text { Energi Primer }\end{array}$} & 169 & 385 & 411 & 402 & 486 & 491 & 501 & 507 & 534 & 544 & 552 & 559 & 545 & 549 & 559 \\
\hline \multirow{6}{*}{$\begin{array}{l}p \\
e \\
f \\
s \\
e \\
n \\
t \\
a \\
s \\
e\end{array}$} & Batubara & 27.0 & 15.5 & 13.8 & 18.2 & 16.6 & 16.9 & 16.1 & 16.1 & 16.4 & 16.5 & 16.4 & 16.9 & 16.4 & 17.4 & 17.9 \\
\hline & Minyak bumi & 59.6 & 77.4 & 71.5 & 56.6 & 58.3 & 56.7 & 58.2 & 56.6 & 57.4 & 55.8 & 55.2 & 53.6 & 52.4 & 52.0 & 51.8 \\
\hline & Gas Alam & 1.2 & 1.5 & 5.2 & 9.8 & 10.1 & 10.6 & 10.6 & 10.7 & 10.8 & 10.8 & 11.4 & 11.6 & 12.3 & 12.7 & 13.1 \\
\hline & Hidro & 10.6 & 4.1 & 4.6 & 4.6 & 4.2 & 4.6 & 3.8 & 4.3 & 2.9 & 3.5 & 3.3 & 3.7 & 3.9 & 3.6 & 3.4 \\
\hline & Energi nuklir & 0.0 & 0.6 & 3.9 & 9.4 & 9.4 & 9.8 & 10.0 & 11.1 & 11.3 & 12.0 & 12.3 & 12.9 & 13.7 & 13.0 & 12.4 \\
\hline & $\begin{array}{l}\text { Energi baru } \\
\text { dan lain-lain }\end{array}$ & 1.5 & 1.0 & 1.0 & 1.3 & 1.4 & 1.4 & 1.3 & 1.3 & 1.2 & 1.3 & 1.3 & 1.4 & 1.3 & 1.3 & 1.3 \\
\hline
\end{tabular}

Source: National Nuclear Energy Agency (https://www.batan.go.id/ensiklopedi/01/02/02/03/03.gif)

Table 1 above shows that in 1973 Japan supplied fuel in the form of petroleum as much as 77.4\% of the total primary energy supply. However, in 1979 and 1986, the amount of petroleum supply was reduced to $71.5 \%$ and $56.6 \%$ of the total primary energy supply in Japan. This shows that from 1973 to 1986 there was a decrease in the amount of oil supply as a result of the world oil crisis in 1973 and 1979.

As a result of the oil crisis, Japan also experienced a high inflation rate in 1973 to 1974. This can be seen in Graph 2 below:

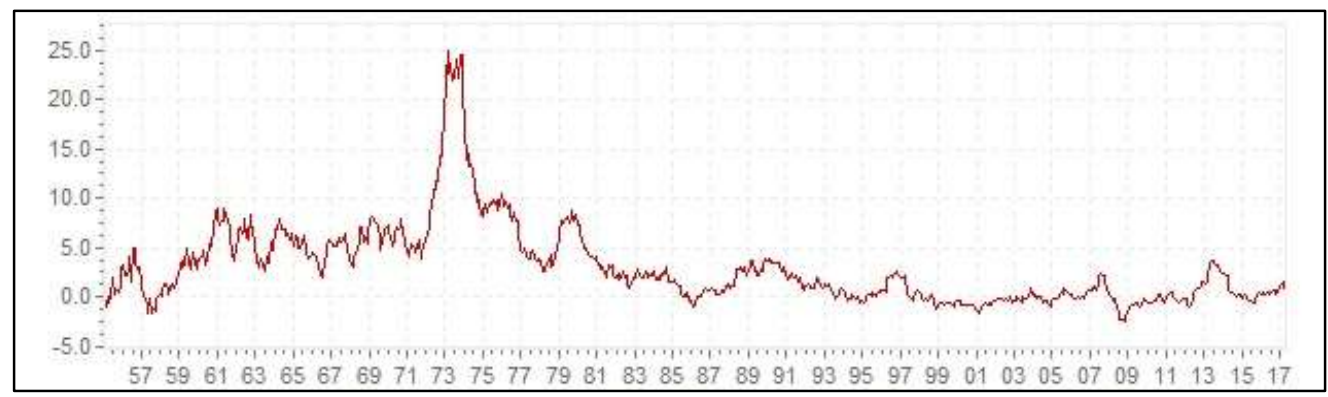

Graph 2. Inflation Rate in Japan

source: data inflation worldwide inflation (www.inflation.eu)

In late 1978, Japan began to rise from adversity due to the oil crisis and high inflation. This is because Japan has begun to develop new energy for its industry in addition to oil energy. In 1980 , the Japanese economy also increased. This rapidly growing economy is characterized by increasing household consumption, an increasing number of skilled and educated workforce, and a stable domestic political situation. The number of productive workforce also increased. This can be seen in Graph 3 below which shows the number of productive ages (labor) in Japan which has increased. 


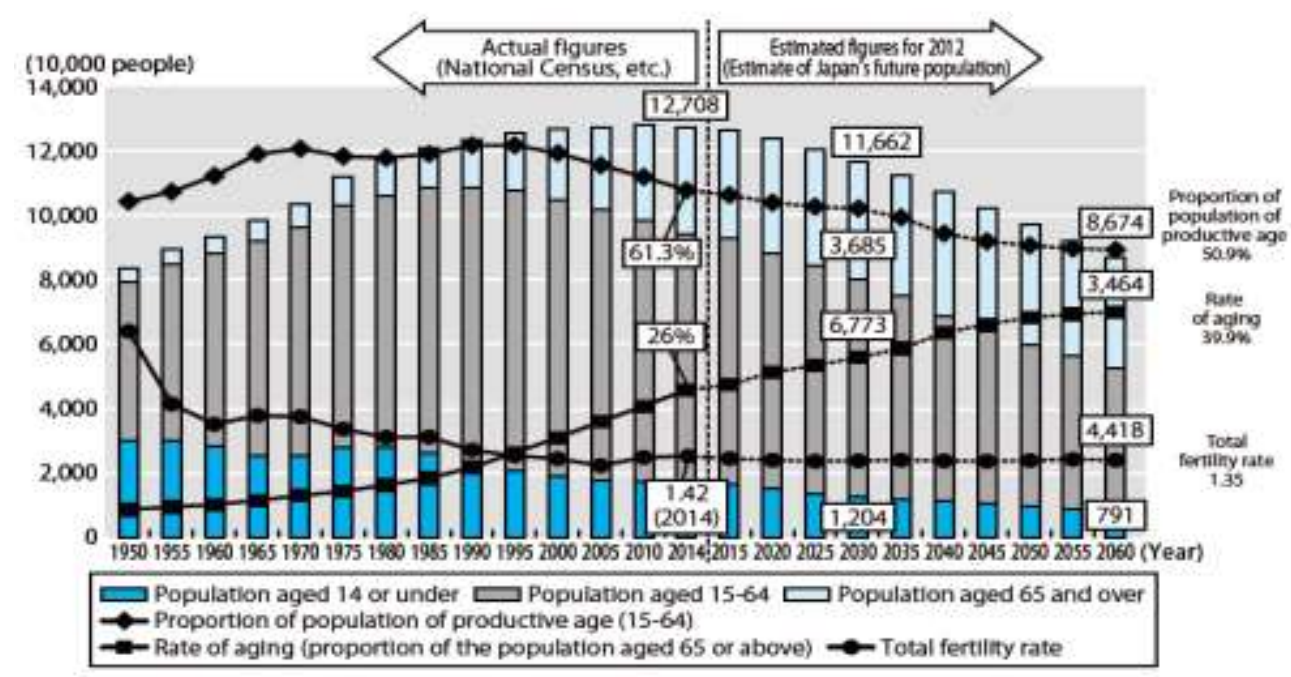

Graph.3 Total population of productive age in Japan source: ministry of home affairs and communication

This rapid economic development caused stock prices and land prices to multiply. This situation makes Japan experience a bubble economy, which is a situation where the level of public consumption is high. With this economic bubble, the company is progressing. To expand its business, many companies open job openings for university graduates. Thus, many university graduates in this period easily find jobs in large companies. In addition, in order to keep the workers loyal to their work, there are many companies that play a role as nakodo or intermediary between male and female workers. This is done by the company in the hope that male workers will continue to work in the company for the welfare of their families. Japan's social and economic conditions that experience change also affect individuals and families.

\section{RESEARCH RESULTS}

From the results of comparing the two stories reflected in the Kazoku Game (1983) movie and Kazoku Game (2013) television drama, it can be seen that Japanese families, relationships and the roles of each family member experience changes, especially the role of mothers in their families and children's education. Below will be discussed about the roles of each family member and the relationships reflected in the movie and in the television drama.

\subsection{Mother's role in the Kazoku Game movie and television drama}

The role of the mother in both movie and television drama, Kazoku Game, is described as a housewife who takes care of all household needs and matters. However, in the Kazoku Game (1983) movie, the mother is portrayed as a person who attaches importance to children's 
education, so she is responsible for managing everything from school, tutoring and so on. In addition, Chikako (mother) is also described as a mother who can scold her child if they make mistakes or asks about her child's activities. She also knew that her son was bullied by his schoolmates. The movie also shows that Chikako is a mother figure who can be used as a place for her children to complain about their problems. Beside being a mother, Chikako also played a good and caring wife to her husband. Chikako always provides meals for Kousuke and her children. Chikako can also be a mediator when there is a debate between Kousuke and their children. The mother figure depicted in the Kazoku Game (1983) movie is a mother figure in a Japanese family who still has an important role in the family. This is different from the mother's figure shown in the Kazoku Game (2013) television drama.

In the Kazoku Ganme (2013) television drama, Kayoko (Mother) was described as a mother who did not know anything about her children. She is also portrayed as a mother who does not care much about her children's education. This is shown in the scene where Shigeyuki performs a hikikomori (confinement in the room), Kayoko as a mother doesn't ask Shigeyuki why he doesn't want to go to school, but she just provides food and others for Shigeyuki. She didn't tell Shigeyuki to go to school and didn't ask why Shigeyuki was doing hikikomori. Kayoko also didn't dare to scold Shin'ichi when she found out Shin'ichi was doing manbiki (stealing in a shop) or damaging other people's things. As a mother, Kayoko felt that she had to protect her children in this way. As a mother, Kayoko did not play the role she should. She was not able to be a place to complain for her children. She was not able to be firm with her children when they made a mistake. Kayoko also gave less attention to her children. This was shown in the scene where Shin'ichi said that Kayoko was not interested in them at all and was busier to herself.

In addition, Kayoko also did not dare to express her feelings to her family. She preferred to keep her feelings and planned to divorce Kazushige after their children entered university. However, as a reflection of the inner pressure that Kayoko felt, she made buying and selling shares which resulted in her having a debt of 10 million yen which must be paid within a month. Therefore, Kayoko tried to commit suicide in order to pay the debt with her life insurance.

Even in neighbors, Kayoko also did not dare to express her dislike for her neighbors when her neighbors threw away the garbage a day faster than the schedule. Besides, Kayoko also did not like to talk about her family's problems, especially her son's problems, Shigeyuki. She always told lie to her neighbors and cover up with lies when her neighbors start asking questions about her family.

From the description of mothers featured in the Kazoku Game (2013) television drama, it can be seen that the role of mothers in Japanese families compared to 1983 had a significant change. Mother is no longer an important figure in the family and the mother also no longer gives more attention to her children and her husband. The mother's figure is described as a person who is more concerned with her own problems.

\subsection{Father's role in the Kazoku Game movie and television drama}

In the movie and television drama of Kazoku Game is described that a father has a role as the head of the family and as a breadwinner to meet family needs. Father did not intervene too much in the household affairs and education of his children. He handed over all household matters to his wife, so he could concentrate on work. However, in the Kazoku Game (1983) movie, it was shown that the father (Kousuke) still had attention to his children's education. This 
was demonstrated by his efforts to find private teachers for his second child who got a decline in achievement in his school. In addition, Kousuke also determines the school to be chosen by his child. This was done by Kousuke, with the hope that later his children would have a more established life and could guarantee his and his wife's life when they become old age. Kousuke was also angry when he knew that Shin'ichi decided not to go to university after graduating from high school and preferred to work. This shows that in 1983, a father in a Japanese family still paid attention to the education of his children.

In contrast to the role and attitude of the father in the Kazoku Game (2013) television drama, Kazushige as a father and head of the family was described as a father who did not care about his family. This is indicated by his ignorance of the cause of Shigeyuki (second child) doing hikikomori (confining himself at home), his ignorance of the reason Kayoko (wife) try to committed suicide and his ignorance of depression suffered by Shin'ichi (first child) as exemplary student. Kazushige is also more concerned with people's views about his image as a good head of family and also as a good senior in the company. This is shown in the scene where Kazushige asks Shigeyuki to go to school so as not to embarrass him. Kazushige also treated a woman who missed her wallet in front of his junior. Then another scene also showed Kazushige feeling embarrassed when he was fired from the company where he worked due to embezzlement of money. He kept wearing a working clothes and went to the office as usual to show to the others that he was still working even though he actually had been fired from the company.

In addition, Kazushige also did not want to acknowledge his weakness. When he was about to apply for a job again, he asked the job search company to find a job with the same position and salary he had received in the previous company. However, job seekers ask Kazushige to realize and accept his true state of affairs and weaknesses. From the description of the father figure featured in the Kazoku Game (2013) television drama, it can be seen that the father figure in the Japanese family is only a breadwinner. The role of the father as the head of the family and the decision maker has not gone well due to the lack of communication between family members and the lack of attention of the father to his family.

\subsection{The relationship between husband and wife}

The husband and wife relationship in the Kazoku Game (1983) movie looked harmonious and there was still communication between husband and wife. Chikako was still able to express her opinions and feelings to Kousuke, her husband. In addition, Chikako is a submissive wife type to husband. She did not argue when Kousuke protested about her cooking. She also rarely goes outside the house beside to go to shopping and go to her children's school. Chikako is always at home when her children need her. When Shigeyuki was confused in deciding which high school he wants to enter, Chikako discussed with Kousuke about the matter. Chikako also always prepared hot water for bathing and providing food for Kousuke.

In the Kazoku Game (2013) television drama, Kazushige and Kayoko's relationship as husband and wife looked cold and there was no communication about family matters. They only carry out their roles as husband and wife and as a father and mother, in which there is no strong emotional and feeling bond. This was seen when Kazushige did not know that Kayoko had a lot of debt and had already cut her relationship with her biological father. Kazushige also had an affair with another woman because his relationship with Kayoko was no longer harmonious. In 
addition, Kazushige always thought that according to Kayoko, he was only a tool for earning a living, so Kazushige did not feel happiness at home. Kazushige also thought that the wife's job was to take care of the household and children, so that he did not interfere too much in the matter of caring for the child. While Kayoko thought that Kazushige was too busy working so he did not have time to help her in household matters. Thinking like that makes Kayoko feel neglected and have no place at home. Kayoko then released the feelings by playing with her neighbors.

\subsection{Relationship between Parents and Children}

In the Kazoku Game (1983) movie, it was shown that Chikako was the mother and Kousuke as Shigeyuki and Shin'ichi's father scolded their children when they skipped school or dropped their rank. Chikako, Kousuke, Shin'ichi and Shigeyuki are portrayed often eating together at the dining table. Chikako also paid attention when Shigeyuki was injured for being beaten by Yoshimoto. Furthermore, Shigeyuki and Shin'ichi also often tell Chikako about the problems they are facing. Shigeyuki and Shin'ichi also still respect Chikako and Kousuke as their parents, so they never say harshly to Chikako and Kousuke. When Chikako told Shigeyuki to meet Yoshimoto, his new private teacher, Shigeyuki did not argue and came to see Yoshimoto. In Shigeyuki and Shin'ichi's education, Kousuke as a father also determines which school is right for his children. Kousuke was also angry when Shinichi decided not to go to university without discussing it with him. Kousuke also felt proud when Shigeyuki managed to raise his grades at school and managed to pass the exam to entry into high school. From the scenes shown in the Kazoku Game (1983)movie, it can be known that the relationship between parents and children is still harmonious and there is mutual dependence between the two. Parents still play the roles as parents and children still respect their parents.

In the Kazoku Game (2013) television drama, it was shown that the relationship between parents and children is just a role relationship, there is no emotional bond in it. This is shown in the scene of Shigeyuki doing hikikomori. His parents (Kazushige and Kayoko) did not scold or ask why he did the hikikomori, but instead provided food and other facilities to support the hikikomori action by Shigeyuki. Then Kayoko as a mother also did not dare to reprimand Shin'ichi who began to commit criminal acts such as manbiki or damage the property of other people. Kazushige also did not dare to reprimand or ask Shigeyuki about the bullying that he got at school. In addition, in the drama there is a scene where Shin'ichi and Shigeyuki express their feelings to Kazushige and Kayoko. Shin'ichi and Shigeyuki feel that their parents are not interested in them at all and are more busy taking care of themselves. Shin'ichi didn't even feel Kayoko or Kazushige noticed them. Shin'ichi just feels depressed with the expectations of parents on him. This distress made him persecute at school and other bad deeds. Shigeyuki also felt that his parents did not pay attention to him at all and felt his parents cared more about the views of others than their children. That's what makes him feel inferior and introvert.

\subsection{Relationship between siblings}

Shin'ichi and Shigeyuki in the Kazoku Game (1983) movie are shown as siblings who can communicate well with each other. Although there is little competition in their relationship, there is no reluctance between the two. Neither are they involved in a fight between siblings and 
there is no feeling of depression with each other's presence. Shin'ichi and Shigeyuki relationships reflected in the Kazoku Game (1983) movie are like siblings' relationships that are common in Japanese society at that time, harmonious and respectful.

Unlike the Kazoku Game (1983) movie, in drama, Shigeyuki and Shin'ichi are described as competing siblings. Shin'ichi tries to be the best child fulfill the expectations of his parents, while Shigeyuki who feels himself continues to be compared with Shin'ichi, feels more insecure, introvert and does not dare to express his feelings in front of others. When Shigeyuki asked Shin'ichi for money to fulfill the demands of his oppressive friend, there was a sense of reluctance in Shigeyuki. He felt a bit afraid of asking Shin'ichi for money. Shin'ichi also doesn't really care about his brother. He knew his brother had been bullied at school, but he did not give any assistance to Shigeyuki. As an older brother who should protect his brother from the threats of others, Shin'ichi only told Shigeyuki to be patient and restrained himself and if Shigeyuki was unable to bear the oppression, Shin'ichi suggested that Shigeyuki stay at home and do not need to go to school.

\subsection{Relationship with other people}

In the movie, neighbors and Yoshimoto do not give a strong influence on family harmony. But in drama, neighbors, co-workers of Kazushige and Yoshimoto (Shigeyuki private tutors) can easily enter the family and influence the fragrance of the Numata family. For example, neighbors easily persuade Kayoko to play stocks. In addition, Kayoko also felt the need to convey to her neighbors the truth of Kazushige's affair with his colleagues. Kayoko also tried to be kind and friendly to her neighbors so as not to be considered bad by her neighbors. In his office, Kazushige's colleagues could easily seduce Kazushige until he had an affair. Kazushige also had to be kind to his junior to show that he was a good senior and superior. Yoshimoto as a private teacher also easily persuaded and played around with all Numata family members as he wished.

\section{CONCLUSION}

Japanese family in 1983, family ties are still very strong. this can be shown by eating together, mothers who pay attention to the health and education of children, the relationship of husband and wife who even though there is a distance, but still discuss together to solve family problems. The role of the mother in the film is still clearly visible and plays an important role in the family. Whereas in the Japanese family which was reflected in the Kazoku Game (2013) television drama, the relationship between parents and children had begun to drift apart due to their respective activities. Similarly, the relationship between husband and wife and the relationship between siblings. In the Kazoku Game (2013) television drama, it was shown that the role of mothers no longer played an important role in determining the education of their children and in household affairs. Mother is more busy taking care of herself and her own interests. In addition, each family member tries to portray their respective roles without daring to show the real feeling. This results in the family life they live just like family life that pretends without showing true feelings. The attitude of parents to children's education was not as hard as in 1983. Even parents are no longer respected and valued by their children. 


\section{ACKNOWLEDGEMENT}

This research based on grant scheme of PITTA (Publikasi International Terindeks untuk Tugas Akhir) or also known as Indexed International Publications for Final Projects toward Universitas Indonesia students. Thank you to The Directorate of Research and Community Engagement of Universitas Indonesia (DRPM UI).

\section{REFERENCES}

[1]. Gerow, Aaron. (2007) Playing With Modernism, Morita Yoshimitsu's The Family Game (1983) in Japanese Cinema: Text and Contexts (pp.240-252). New York: Routledge.

[2]. Imamura, E. Anne (1992). Urban Japanese Housewives at Home and In The Community. Honolulu: University of Hawaii Press.

[3]. Kimoto, Kimiko. (1997). Company Man Makes Family Happy: Gender Analysis of The Japanese Family. Hitotsubashi Journal of Social Studies, 29, 1-17.

[4]. Labor Situation In apan and Its Analysis: General Overview 2015/2016. Chapter 1 Japanese Economy and Labor Situation (pp.14-19).

[5]. Mcdonald, I. Keiko. (1989). Family, Education and Postmodern Society: Yoshimitsu Morita's The Family Game. East-West Film Journal. vol 4.no.1,53-67.

[6]. Ochiai, Emiko. (1994). The Japanese Family System in Transition, A Sociological Analysis of Family Change in Postwar Japan. Japan: LTCB International Library Foundation. Yuhikaku Publishing Co. Ltd.

[7]. Ohno, Kenichi. (2006). The Economic Development of Japan, The Path Traveled by Japan as a Developing Country. Tokyo: GRIPS Development Forum. Yuhikaku Publishing Co. Ltd.

[8]. Thorarinsson, Loftur. (2018). A Review of The Evolution of The Japanese Oil Industry, Oil Policy and Its Relationship with The Middle East. Oxford Institute of Energy Studies. OIES Paper: WPM 76.

[9]. Alamsyah Saragih. (2015) Jepang dan Dekade yang Hilang. hlm. https://www.kompasiana.com/alamsyahsaragih/jepang-dan-dekade-yanghilang_562b83e3c1afbd1b09857d14, 9 Desember 2015, pk 13.28 WIB

[10]. Towmey, Bryan https://www.investopedia.com/articles/forex/09/plaza-accord.asp tentang plaza accord

[11]. http://www.batan.go.id/ensiklopedi/01/02/02/05/01-02-02-05.html diakses pada 5 April 2017 pukul 12:06 WIB.

[12]. Www. youtube/the family game 1983.

[13]. www. gooddrama/kazokugame (2013) 